\title{
Mitigating AMD Impacts in New Zealand Using Engineered Wetlands ${ }^{1}$
}

\author{
Craig A. McCauley ${ }^{2}$, Aisling D. O'Sullivan ${ }^{2,3}$, Paul Weber ${ }^{2}$ and Phil Lindsay ${ }^{2}$
}

\begin{abstract}
Coal mining in New Zealand has caused perturbation of water resources and biodiversity. Contaminants impairing local waterbodies include acidity, iron, aluminum, arsenic, manganese, nickel, zinc, copper, sulfate and suspended solids. Exposure of sulfur containing rocks, such as pyrite, to atmospheric oxygen during mining operations produces acid mine drainage (AMD). Sulfuric acid and metal acidity are generated and can accentuate metal mobilization and bioavailability. Metals favor the dissolved state in acidic environments but form less toxic precipitates when exposed to adequate alkalinity. Metal toxicity effects are synergistic dependent on metals speciation and their concentrations.
\end{abstract}

New Zealand is in the initial stages of acid mine drainage mitigation and has yet to develop proven treatment technologies. Implementation of passive treatment methods, such as engineered wetlands, have successfully reduced acid mine drainage impacts worldwide. Design criteria for these systems are improving while their limitations are well documented. We are currently collecting water quality and flow data from selected AMD-impacted sites. We are in the process of designing pilot-scale engineered wetland systems to ameliorate acid mine drainage in New Zealand. Sequential-treatment trains will be constructed and their performance evaluated in order to optimize design effectiveness.

New Zealand acid mine drainage characteristics and complex topography offer unique challenges for implementing treatment systems. The AMD typically contains very high aluminum concentrations (commonly exceeding $50 \mathrm{~g} / \mathrm{m}^{3}$ ) and has an aluminum to iron concentration ratio of three to one. Abundant steep topography can be exploited to create adequate driving head for implementing systems such as SCOOFI reactors while reducing and alkalinity producing systems can also be employed. Precipitation of up to six meters per year contributes to dynamic hydraulic characteristics and will offer unique design and treatment challenges.

Additional Key Words: aluminum, iron, water quality, New Zealand, acid mine drainage, coal mining, steep topography

\footnotetext{
${ }^{1}$ Poster was presented at the 2006, $7^{\text {th }}$ ICARD, March 26-30, 2006, St. Louis, MO. Published by ASMR, 3134 Montavesta Rd., Lexington, KY 40502.

${ }^{2}$ Craig A. McCauley, PhD candidate, Department of Civil Engineering (Natural Resources Engineering Group), University of Canterbury, Private Bag 4800, Christchurch 8020, New Zealand, Email: craig.mccauley@canterbury.ac.nz, Ph: 64-3-364-2987 ext. 7332, Fax: 64-3-364-2758. Aisling D. O’Sullivan, Lecturer (equivalent to Assistant Professor in U.S.), Department of Civil Engineering (Natural Resources Engineering Group), University of Canterbury, Email: aisling.osullivan@canterbury.ac.nz, Ph: 64-3-364-2252, Fax: 64-3-364-2758. Paul Weber and Phil Lindsay, Environmental Research Manager and Environmental Operations Manager, Solid Energy New Zealand Limited, P.O. Box 1303, Christchurch, New Zealand, Email: paul.weber@solidenergy.co.nz or phil.lindsay@solidenergy.co.nz, Ph: 64-3-345-6000, Fax: 64-3-345-6016.

${ }^{3}$ Presenting the poster paper.
} 


\section{$\underline{\text { Introduction }}$}

It is reported that coal mining in New Zealand began in the 1830 s with mining districts becoming established in the 1870s for commercial purposes (Pattrick, 2004, Solid Energy, 2005). Solid Energy New Zealand Limited (SENZ) represents a state owned and operated coal company developing from a government trading enterprise established in 1901 and privatized in 1987 as Coal Corporation of New Zealand. Current production exceeds 4 billion kilograms of coal annually from its seven underground and opencast mines in the North and South Islands (Solid Energy, 2005). Most acid mine drainage (AMD) impacts occur on the South Island from estuarine coal formations containing high concentrations of sulfur (Pers. Comm. Paul Weber, Environmental Research Manager SENZ, 2005). North Island coals and a significant amount of South Island coals do not typically generate AMD since they formed from lacustrine accretions containing low sulfur concentrations. Historical coal mining has resulted in contamination of numerous streams with AMD. Solid Energy inherited many of these environmental liabilities and are in the initial stages of addressing AMD impacts from historical and current mining activities. The contents of this report will focus on AMD issues from South Island coal mining as these sites are most impacted by AMD.

\section{Problem Statement}

Numerous streams in New Zealand contain high concentrations of acidity and metals from unabated AMD runoff. Carbonaceous mudstones and coal represent the primary sources of acidity by producing sulfuric acid when exposed to oxygen (Trumm et al., 2005). Metal cations also contribute acidity upon hydrolyzing with water. Metals from the parent rock material leach into the aqueous phase when exposed to acidity. Sandstones abutting the mudstones contribute metals leachate, and some sulfur, when exposed to acidity but are not the major acidity contributors.

Pyrite $\left(\mathrm{FeS}_{2}\right)$ represents the primary source of iron. The primary sources of aluminum include potassium feldspar or microcline $\left(\mathrm{KAlSi}_{3} \mathrm{O}_{8}\right)$, muscovite $\left(\mathrm{KAl}_{2}\left(\mathrm{AlSi}_{3} \mathrm{O}_{10}\right)(\mathrm{F}, \mathrm{OH})_{2}\right)$ and kaolinite $\left(\mathrm{Al}_{2} \mathrm{Si}_{2} \mathrm{O}_{5}(\mathrm{OH})_{4}\right)$. The sequence of reactions for pyrite oxidation is well documented (e.g. Watzlaf et al., 2003). However, it is important to note that following initial pyrite 
oxidation, ferric iron acts as an oxidizing catalyst for acidity generation. This reaction is summarized as follows (Equation 1):

$$
\begin{gathered}
\mathrm{FeS}_{2}+14 \mathrm{Fe}^{3+}+8 \mathrm{H}_{2} \mathrm{O} \rightarrow 15 \mathrm{Fe}^{2+}+2 \mathrm{SO}_{4}{ }^{2-}+16 \mathrm{H}^{+} \\
\text {Pyrite }+ \text { Ferric Iron }+ \text { Water } \rightarrow \text { Ferrous Iron }+ \text { Sulfate }+ \text { Acidity }
\end{gathered}
$$

When potassium feldspar is exposed to acidity, kaolinite and silicic acid are produced (Equation 2) (Younger et al., 2002; Watzlaf et al., 2003). Kaolinite is further degraded by acidity, resulting in mobile aluminum ions (Equation 3). Aluminum precipitates in the presence of water (measured at a $\mathrm{pH}=4.8$ from Stockton Mine Water (Pers. Comm. Joseph Holman, Environmental Engineering Lab Technician, University of Canterbury, 2005)) and produces acidity (Equation 4). Thus, aluminum-containing rock which is exposed to proton acidity results in the release of aluminum (Equations 2 and 3), coupled with the production of acidity upon aluminum hydroxide formation (Equation 4), and so the process of aluminum released into solution can be perpetuated. In New Zealand West Coast rock formations, aluminum-containing rocks and low $\mathrm{pH}$ (typically near or less than 3) contribute to the relatively high aluminum to iron proportions uncharacteristic of the majority of AMD water elsewhere.

$$
\begin{gathered}
\mathrm{KAlSi}_{3} \mathrm{O}_{8}+\mathrm{H}^{+}+9 / 2 \mathrm{H} 2 \mathrm{O} \rightarrow 2 \mathrm{H}_{4} \mathrm{SiO}_{4}+1 / 2 \mathrm{Al}_{2} \mathrm{Si}_{2} \mathrm{O}_{5}\left(\mathrm{OH}_{4}\right) \\
\text { Potassium Feldspar }+ \text { Acidity }+ \text { Water } \rightarrow \text { Silicic Acid }+ \text { Kaolinite } \\
\mathrm{Al}_{2} \mathrm{Si}_{2} \mathrm{O}_{5}\left(\mathrm{OH}_{4}\right)+6 \mathrm{H}^{+} \rightarrow 2 \mathrm{Al}^{3+}+2 \mathrm{H}_{4} \mathrm{SiO}_{4}+\mathrm{H}_{2} \mathrm{O} \\
\text { Kaolinite }+ \text { Acidity } \rightarrow \text { Aluminum Ions }+ \text { Silicic Acid + Water } \\
\mathrm{Al}^{3+}+3 \mathrm{H}_{2} \mathrm{O} \rightarrow \mathrm{Al}(\mathrm{OH})_{3}+3 \mathrm{H}^{+} \\
\text {Aluminum Ions }+ \text { Water } \rightarrow \text { Aluminum Hydroxide (ppt })+ \text { Acidity }
\end{gathered}
$$

Other metals such as arsenic, manganese, nickel, zinc and copper can also leach from source rocks under acidic conditions and increase AMD toxicity to aquatic species. 


\section{Proposed Methodology}

Passive treatment systems are proven treatment technologies if designed and implemented properly (Younger et al., 2002). Possible systems may include inorganic media passive systems (IMPs). Candidate IMPs include surface catalyzing oxidation of ferrous iron reactors (SCOOFIs) to exploit the New Zealand steep topography and oxic limestone drains and openchannel limestone reactors to generate alkalinity. Engineered wetland types appropriate for New Zealand AMD include sedimentation ponds, reducing and alkalinity producing systems (RAPS), sulfate-reducing bioreactors (such as compost wetlands) and aerobic wetlands, amongst others.

Our research consists of designing and evaluating the performance of multiple pilot-scale engineered wetlands to determine which systems offer the most cost effective treatment options for ameliorating AMD. The initial six-month period will consist of characterisation of AMD at the research field site. Characterisation of samples will quantify contaminant concentrations and loading variability during periods of high and low flows. Basic water quality parameters including $\mathrm{pH}$, turbidity, conductivity and temperature will be continuously recorded using data loggers. Flow ranges will also be recorded using data loggers. Multiple sampling trips will aim to comprehensively characterise the variability in seasonal loadings of metal contaminants to the impacted watershed.

Design criteria developed overseas will be adopted for choosing and sizing system designs. Systems will be designed and constructed to include adequate replication and variation in design parameters. Different cell sequences will be considered to evaluate their treatment effectiveness. Rates of sedimentation and precipitation of metal-hydroxides, their rate-limiting steps and characterising water throughout the treatment process, in addition to materials used and cost implications, will be considered in the final designs.

Water and soil substrate samples will be collected and analysed periodically to determine chemical dynamics and metal speciation within the systems. This data will provide information on the chemical transformations and consequent treatment efficiency of the systems. Chemical modelling will be performed to evaluate treatment limits based on treatment performance 
measured from flow and chemical data. An evaluation of the long term suitability of these systems and the potential for metal precipitates to remobilize will be considered. Results will also be used to develop design criteria for passive treatment systems at other sites Because every site is heterogeneous and offers unique challenges, system designs will be modified based on site characteristics, constraints, flow and contaminant concentrations. Since this project officially commences January 2006, we have not yet ascertained the most appropriate designs. These will depend on contaminant loading regimes deciphered by May 2006.

\section{$\underline{\text { Site Selection }}$}

The site where the trialed engineered wetlands will be constructed is under final consideration. Efforts will focus on AMD on the West Coast of the South Island where unique challenges such as high aluminum concentrations and six meters of rainfall annually predominate. A summary of candidate sites including advantages and disadvantages of site selection is given in Table 1. At present, Sullivan Mine is the preferred site for rehabilitating since it offers the best rehabilitation return for the efforts expended (see advantages).

\section{Current Data}

Sporadic water quality and flow data exists for numerous AMD sources and streams impacted by AMD on the West Coast. However, data collection has not been consistent, quality assured or considered analytes necessary to obtain adequate design criteria at most sites. The $\mathrm{pH}$ in many West Coast South Island streams is naturally acidic fluctuating between 4.0 and 5.0 (Harding, 2005). The pH of AMD is commonly less than 3.0 at source and throughout some impacted streams (Trumm et al., 2005). Background aluminum concentrations in some nonAMD impacted streams can also exceed permitted trigger values (Pers. Comm. Phil Lindsay, Environmental Operations, SENZ, 2005). At the Stockton site, acidity can range between 200$800 \mathrm{~g} \mathrm{CaCO}_{3} / \mathrm{m}^{3}$, dissolved ferrous iron of $15-50 \mathrm{~g} / \mathrm{m}^{3}$, dissolved aluminum of $50-100 \mathrm{~g} / \mathrm{m}^{3}$ and sulfates from $200-800 \mathrm{~g} / \mathrm{m}^{3}\left(1 \mathrm{~g} / \mathrm{m}^{3}=1 \mathrm{mg} / \mathrm{L}\right)$. Data collected from Sullivan Mine AMD between February 2001 and June 2002 contained an average $\mathrm{pH}$ of $2.8,192 \mathrm{~g}$ acidity $/ \mathrm{m}^{3}$ as $\mathrm{CaCO}_{3}, 366 \mathrm{~g}$ sulfate $/ \mathrm{m}^{3}, 13.75 \mathrm{~g}$ dissolved aluminum $/ \mathrm{m}^{3}, 0.012 \mathrm{~g}$ dissolved arsenic $/ \mathrm{m}^{3}, 41.58 \mathrm{~g}$ 
dissolved iron $/ \mathrm{m}^{3}, 0.5 \mathrm{~g}$ dissolved manganese $/ \mathrm{m}^{3}, 0.12 \mathrm{~g}$ dissolved nickel $/ \mathrm{m}^{3}$ and $0.7 \mathrm{~g}$ dissolved zinc $/ \mathrm{m}^{3}$ (Trumm et al., 2005). These concentrations for $\mathrm{Al}, \mathrm{Fe}, \mathrm{Ni}$ and $\mathrm{Zn}$ were all above the acceptable trigger values stipulated in New Zealand legislation (ANZECC, 2000).

Table 1. Site selection potential and priorities.

\begin{tabular}{|c|c|c|c|}
\hline Site & Advantages & Disadvantages & Additional Comments \\
\hline $\begin{array}{l}\text { Echo Mine/ } \\
\text { Island Block }\end{array}$ & $\begin{array}{l}\text { 1) Likely improvement of water } \\
\text { quality and biodiversity. } \\
\text { 2) Good location for assessing } \\
\text { effectiveness of SCOOFIs } \\
\text { because of steep topography. } \\
\text { 3) Closest site to offices in } \\
\text { Christchurch. }\end{array}$ & $\begin{array}{l}\text { 1) Active mining from other } \\
\text { companies on site. } \\
\text { 2) High level of uncertainty of } \\
\text { controlling system inputs } \\
\text { because of active mining. } \\
\text { 3) Adequate land area not } \\
\text { available at all potential sites. } \\
\text { 4) Construction equipment and } \\
\text { materials would have to be } \\
\text { brought in from offsite. }\end{array}$ & $\begin{array}{l}\text { 1) Multiple potential sites. } \\
\text { 2) Three separate streams } \\
\text { receiving AMD. } \\
\text { 3) Most logical trial system } \\
\text { site based on available land } \\
\text { area and current mining } \\
\text { operations would only } \\
\text { protect a few hundred } \\
\text { meters of stream. }\end{array}$ \\
\hline Stockton & $\begin{array}{l}\text { 1) Likely improvement of water } \\
\text { quality and biodiversity. } \\
\text { 2) Actively mined by SENZ so } \\
\text { construction equipment and } \\
\text { technical/logistical support } \\
\text { available on site. } \\
\text { 3) Adequate land area. }\end{array}$ & $\begin{array}{l}\text { 1) Active mine with } \\
\text { uncertainties regarding } \\
\text { controlling system inputs such } \\
\text { as sediment loading. } \\
\text { 2) Furthest site from offices in } \\
\text { Christchurch. }\end{array}$ & $\begin{array}{l}\text { 1) Multiple potential sites. } \\
\text { 2) High political pressure to } \\
\text { mitigate AMD issues here. } \\
\text { 3) Receives the highest } \\
\text { rainfall of all potential sites } \\
\text { and also has the highest } \\
\text { aluminum concentrations. }\end{array}$ \\
\hline Sullivan & $\begin{array}{l}\text { 1) Likely improvement of water } \\
\text { quality and biodiversity. } \\
\text { 2) Adequate land area. } \\
\text { 3) Underground abandoned } \\
\text { mine with consistent flow from } \\
\text { adit prior to discharging into } \\
\text { impacted stream. } \\
\text { 4) Most data available of all the } \\
\text { site options. } \\
\text { 5) Located in a highly valued } \\
\text { recreational area with } \\
\text { numerous hiking trails. } \\
\text { 6) Treating the major } \\
\text { contaminant source would } \\
\text { reduce most AMD inputs into } \\
\text { impacted stream and therefore } \\
\text { allow for feasible stream } \\
\text { restoration. }\end{array}$ & $\begin{array}{l}\text { 1) Construction equipment and } \\
\text { materials would have to be } \\
\text { brought in from offsite. } \\
\text { 2) Minor road repairs need on } \\
\text { access road. }\end{array}$ & $\begin{array}{l}\text { 1) Two adits contribute } \\
\text { AMD to Rapid Stream with } \\
\text { most of the contaminant } \\
\text { contribution ( } 99 \text { percent or } \\
\text { more) from the lower adit. }\end{array}$ \\
\hline
\end{tabular}

\section{Regulatory Criteria}

The lack of historical background water quality data and dominance of endemic aquatic organisms in New Zealand make determining acceptable regulatory criteria challenging for freshwater environments (Harding et al., 2005). Overseas toxicity data must be used with 
caution in the New Zealand context. New Zealand environmental law is mandated in the Australian and New Zealand Environment and Conservation Council (ANZECC) Water Quality Guidelines (ANZECC, 2000). Applicable toxicity data for freshwater ecosystems is represented as trigger values with four levels of protection based on percent of species not affected as shown in Table 2. The 80-precent level of protection trigger values are typically mandated by local regional councils for streams impacted by AMD.

Table 2. ANZECC trigger values $\left(\mathrm{g} / \mathrm{m}^{3}\right)$ for freshwater toxicants (ANZECC, 2000)

\begin{tabular}{|c|c|c|c|c|}
\hline \multirow[t]{2}{*}{ Element } & \multicolumn{4}{|c|}{ Level of Protection (\% Species) } \\
\hline & $99 \%$ & $95 \%$ & $90 \%$ & $80 \%$ \\
\hline $\mathrm{Al}(\mathrm{pH}<6.5)$ & ID* & ID* & ID* & ID* \\
\hline $\mathrm{Al}(\mathrm{pH}>6.5)$ & 0.027 & 0.055 & 0.080 & 0.015 \\
\hline $\mathbf{A s}^{3+}$ & 0.001 & 0.024 & 0.094 & 0.360 \\
\hline $\mathbf{A s}^{5+}$ & 0.0008 & 0.013 & 0.042 & 0.140 \\
\hline $\mathbf{F e}$ & ID* & ID* & ID* & ID* \\
\hline Mn & 1.20 & 1.90 & 2.50 & 3.60 \\
\hline $\mathbf{N i}$ & 0.008 & 0.011 & 0.013 & 0.017 \\
\hline $\mathbf{Z n} * *$ & 0.0024 & 0.0080 & 0.015 & 0.031 \\
\hline $\mathrm{Cu} * *$ & 0.0010 & 0.0014 & 0.0018 & 0.0025 \\
\hline
\end{tabular}

* ID indicates insufficient data.

** The values listed assume a hardness value of $30 \mathrm{~g} / \mathrm{m}^{3}$ as $\mathrm{CaCO}_{3}$.

\section{$\underline{\text { Conclusions }}$}

Passive treatment systems including engineered wetlands have been implemented worldwide for successfully ameliorating AMD. It is believed that engineered wetlands can be successfully utilized in New Zealand once adequate water quality and flow data is collected and analyzed (O’Sullivan, 2005). Before appropriate designs can be developed, research needs to be conducted to optimize system designs and sizing. Cost-analysis needs to be performed to determine benefits and feasibility of engineered wetlands versus adopting more active (traditional) chemical dosing treatment approaches. Long-term monitoring should be conducted 
to verify system function and determine long-term applicability. Maintenance such as solids removal must be performed to ensure long term operation and prevent the systems from clogging with sediment, ferric and aluminium hydroxides.

\section{$\underline{\text { Literature Cited }}$}

Australian and New Zealand Environment and Conservation Council (ANZECC) and Agricultural and Resource Management Council of Australia and New Zealand. 2000. Australian and New Zealand Environment and Conservation Council (ANZECC) water quality guidelines.

Harding, J.S. 2005. Impacts of metals and mining on stream communities. In: Moore, T.A., Black, A., Centeno, J.A., Harding, J.S. and Trumm, D.A. (Eds.). Ch. 17. Metal contaminants in New Zealand: sources, treatments, and effects on ecology and human health, pp. 343-357. Resolutionz Press, Christchurch.

O’Sullivan, A.D. 2005. Passive treatment technologies for managing metal mine waster: lessons

learnt from global applications. In: Metal contaminants in New Zealand, (Eds) Moore, T.A., Black, A., Centeno, J.A., Harding, J.S. and Trumm, D.A. Ch.14. pp. 279-299. Resolutionz Press, Christchurch.

Pattrick, J. 2004. Heart of Coal. Black Swan Press, p.333.

Solid Energy New Zealand Limited. www.coalnz.com. October 6, 2005.

Trumm, D., Black, A., Gordon, K., Canach, J., O’ Halloran, K, and de Joux, A. 2005. Acid Mine Drainage Assessment and Remediation at an Abandoned West Coast Coal Mine . In: Moore, T.A., Black, A., Centeno, J.A., Harding, J.S. and Trumm, D.A. (Eds.). Ch. 16. Metal contaminants in New Zealand: sources, treatments, and effects on ecology and human health, pp. 317-340. Resolutionz Press, Christchurch.

Watzlaf, G., Schroeder, K., Kleinmann, R., Kairies, C. and Nairn, R. 2003. The passive treatment of coal mine drainage. 72 pp. Information Circular, National Energy Technology Laboratory, US Department of Energy.

Younger, P., Banwart, S., and Hedin, R., 2002. Mine water: hydrology, pollution, remediation, 442pp. Kluwer Academic, London. 